\title{
Innovative Methods of Teaching for Under Graduate Students
}

\author{
Ravi M. Sambrani ${ }^{1 *}$, Sidram B. ${ }^{2}$
}

\section{ABSTRACT}

A study was conducted in the College of Agriculture, UAS, Raichur during the year 2013-14, to know the benefits as expressed by the students about innovative methods of teaching for under graduate B.Sc. (Agri.) students. The 2nd and 3rd year B.Sc. (Agri) students of the college of Agriculture, Raichur constituted the population. From each class sixty students were selected by simple random sampling procedure to form the sample size of 120 . Keeping the objectives and review of literature in view an interview schedule was prepared, which was pre-tested and standardized to avoid ambiguity. The study revealed that, Three fifth $(60.00 \%)$ of the students were native to the rural areas but their mean grade was 7.21 which is less than the mean grade (8.04) of the students from urban area $(40.00 \%)$. With respect to innovative methods of teaching, large majority (98.33\%) of the students expressed interactive boards are very good innovative teaching tools as it create interest among the learners and teacher followed by discussion method of teaching $(95.00 \%)$ as it facilitates for horizontal flow of knowledge and exposure visits (90.00\%) as it gives clear knowledge about real life situation. The others like, video/audio conferencing, role play and Power Point presentations expressed by 84.17, 82.50 and 80.00 per cent of the students, respectively. Whereas, 63.33, 58.33, 56.67 and 55.83 per cent of students told seminar method, case study method, participatory techniques and demonstrations are the next most important method of teaching, respectively.

Keywords: Teaching, Innovative method, undergraduates, Agriculture and knowledge.

Formal Education, in its broadest sense, may be stated as a process designed to inculcate the knowledge, skills and attitudes necessary to enable individuals to cope effectively with their environment. Its primary purpose is to foster and promote the fullest performance in the given task or activities. Students are most essential asset and their academic performance plays an important role in producing the best quality graduates who will become great leader and manpower for the country, thus they all responsible for the country's economic and social development. Academic performance is very much important for the successful development of

\footnotetext{
${ }_{1}^{1}$ Associate Professor of Psychology, College of Agriculture, UAS, Campus Raichur (Karnataka State)

${ }^{2}$ Assistant Professor of Agril. Extension Education, Department of Agricultural Extension Education, College of Agriculture, UAS, Campus Raichur (Karnataka State)

*Responding Author

(C) 2016 I R Sambrani, Sidram. B; licensee IJIP. This is an Open Access Research distributed under the terms of the Creative Commons Attribution License (http://creativecommons.org/licenses/by/2.0), which permits unrestricted use, distribution, and reproduction in any Medium, provided the original work is properly cited.
} 
young people in society. The academic performance depends on the teaching in the institute as well as the interest, intelligence, hard work and mental ability of the student. The teaching and the teacher are the most important aspects in the development and performance of the students, teaching makes most effective when teacher uses innovative teaching methods for teaching to making teaching more interesting and creates situation to learn easily. Teaching is creation of situation in which learning takes place effectively, so it is not only important to have the better knowledge and experience about the subject but also requires the usage of suitable teaching method. A good match between students' learning preferences and instructor's teaching style has been demonstrated to have positive effect on student's performance (Harb and El Shaarawi, 2006). Selection of any teaching method is depends on the learner's knowledge and capability, hence many educational institutes using innovative teaching methods so has to facilitate for better learning. There are number of innovative methods using in teaching, but each teaching methods has advantages attached with constraints. Keeping this in view a study was conducted in College of Agriculture, Raichur (Karnataka) with undergraduates to know the innovative teaching methods and their effectives.

\section{METHODOLOGY}

The study was conducted in the College of Agriculture, Raichur in the year 2013-14. The Ex-post facto research design was employed has the phenomenon has already occurred. All the $2^{\text {nd }}$ and $3^{\text {rd }}$ year B. Sc. (Agri.) students of the College of Agriculture, Raichur constitute the population for the study. From each class (i.e. $2^{\text {nd }}$ and $3^{\text {rd }}$ year B.Sc. (Agri.)) 60 students were selected by employing simple random procedure to form the sample size of 120 . Keeping objective in view an interview schedule was prepared and which was pre-tested and standardized to minimize the error. The data were collected by personal interview method. The frequency, percentage and mean were used to analyze and tabulate the collected data.

\section{RESULTS AND DISCUSSION}

\section{Personal information of the students:}

A perusal of Table 1 depicts that, Three fifth (60.00\%) of the students were native to the rural areas but their mean grade was 7.21 which is less than the mean grade (8.04) of the students from urban area (40.00\%). The reason might be that the facility and the opportunity for rural students are comparatively less than the urban area students. Pardeep et al. (2010) reported that, urban students performed academically better than rural students but general thinking is that rural students should perform better in agriculture.

With regard to type of family, a large majority (81.67\%) of the students belonged to the nuclear family and only 18.33 per cent of the students belonged to joint family, even though large majority students from nuclear family but the performance of the students from joint family is better than the students from nuclear family, the monitoring and support from the elders in the joint family might have contributed for their better performance. 
With regard to gender girls (46.67\%) performance (mean grade 7.98 ) was better than the boys (53.33 \%) performance (mean grade 7.55 ). The plausible reason might be that, boys spend their most of the time for co-curricular and other activities. Ogweno et al. (2014) reported that, female students had a slightly higher mean of (48.30) compared to performance of male students which had a mean of (47.65).

\section{Parents occupation:}

The data presented in the Table 2 reveals that, considerable (43.33\%) per cent of student's parents occupation was farming followed by government employee (36.67\%), business (30.00 $\%)$ and private employee (28.33 \%). With respect to students academic the performance, whose parents are government servant performed better with mean grade of 8.24 followed by farming (7.31), private employee (7.11) and business (6.74). The reason might be that the government employers are well educated and because of economic stability they can give much attention and monitor their children's education status and can mould as and when required.

\section{Overall performance of students:}

A glance of results presented in the Table 3 indicated that, a considerable percentage (41.67\%) of the students belonged to medium level of performance followed by high (36.67\%) and low (21.67\%) performance level. The results tending towards medium to high performance, the possible reason might be that the minimum grade for passing is 5.00 so, students has to strive hard to get pass in the B.Sc. (Agri.) courses. The quality of teaching and the facilities available for learning in the institution also contribute the performance of the students.

\section{Benefits of innovative methods of teaching as expressed by the students}

The data presented in the Table 3 depicts that, large majority (98.33\%) of the students expressed interactive boards are very good innovative teaching tools as it create interest among the learners and teacher followed by discussion method of teaching (95.00\%) as it facilitates for horizontal flow of knowledge and exposure visits (90.00\%) as it gives clear knowledge about real life situation.

The video/audio conferencing (84.17\%) teaching method is the next priority method expressed by the students as it gives scope for sharing knowledge and between the institutions and experts from different places while, role play and power point presentations was good expressed by 82.50 and 80.00 per cent of the students as these methods increases the efficiency of the students and usage of picture, graphs, charts give clear understanding of the subject, respectively.

Whereas, 63.33, 58.33, 56.67 and 55.83 per cent of students told seminar method, case study method, participatory techniques and demonstrations are the next most important method of teaching methods as these methods gives deep insight about the subject, motivates students for initiation of action and creates interest, participation make students to remember subject for long period and demonstrations improves the students skills and decision making capacity. 


\section{CONCLUSION}

The steps of learning are getting the attention, creation of interest, which produces the desire for learning, than stimulates for action at the end satisfaction of learning. To make learning effective it is important to engage maximum senses of learner. The students learn fast and easily by those methods which involves more practical than the theory and also with those methods which creates interest and provides real life situation experiences in learning process. Hence, the innovative teaching methods are very much best suitable for teaching of undergraduate students for teaching and learning process.

\section{REFERENCES}

Harb, N., and El Shaarawi, A. (2006). Factors affecting student performance. Munich Personal RePEc Archive Paper No. 13621. Accessed on November 02, 2011 from http://mpra.ub.uni-muenchen.de/13621/

Ogweno, P. O., Kathuri, N, N. and Obara, J., (2014) Influence of Students Characteristics on Academic Performance in Secondary Agriculture, in Rachuonyo North Sub County, Kenya, International Journal of Education and Research, Vol 2, No. 3, pp 1-12.

Pardeep, K., Reena, Nasib, S. and Meena, (2010) Rural, Urban Background and Academic Performance of Agriculture Students, Agricultural Science Digest, Vol 30, No. 1, pp 7576.

Table 1: Personal information of the students $\mathbf{n}=\mathbf{1 2 0}$

\begin{tabular}{|c|c|c|c|c|}
\hline Sl. No. & Attributes & $\mathbf{F}$ & $\%$ & Mean Grade \\
\hline \multirow[t]{3}{*}{1.} & \multicolumn{4}{|l|}{ Native: } \\
\hline & Rural & 72 & 60.00 & 7.21 \\
\hline & Urban & 48 & 40.00 & 8.04 \\
\hline \multirow[t]{3}{*}{2.} & \multicolumn{4}{|l|}{ Type of family: } \\
\hline & Nuclear & 98 & 81.67 & 7.54 \\
\hline & Joint & 22 & 18.33 & 7.74 \\
\hline \multirow[t]{3}{*}{3.} & \multicolumn{4}{|l|}{ Gender: } \\
\hline & Boys & 64 & 53.33 & 7.55 \\
\hline & Girls & 56 & 46.67 & 7.72 \\
\hline
\end{tabular}

F=Frequency $\quad \%=$ Percentage


Table 2: Parents occupation

$\mathrm{n}=\mathbf{1 2 0}$

\begin{tabular}{|l|l|c|c|c|}
\hline Sl. No. & \multicolumn{1}{|c|}{ Occupation } & F & \% & Mean Grade \\
\hline 1. & Farming & 52 & 43.33 & 7.31 \\
\hline 2. & Government employee & 44 & 36.67 & 8.24 \\
\hline 3. & Business & 36 & 30.00 & 6.78 \\
\hline 4. & Private employee & 34 & 28.33 & 7.11 \\
\hline
\end{tabular}

Table 3: Benefits of innovative methods of teaching as expressed by the students $\mathrm{n}=\mathbf{1 2 0}$

\begin{tabular}{|c|c|c|c|c|}
\hline $\begin{array}{l}\text { Sl. } \\
\text { No. }\end{array}$ & $\begin{array}{l}\text { Innovative teaching } \\
\text { methods }\end{array}$ & Benefits & $\mathbf{F}$ & $\%$ \\
\hline 1. & Interactive board & $\begin{array}{l}\text { Create interest among the learners and } \\
\text { teacher }\end{array}$ & 118 & 98.33 \\
\hline 2. & Power point presentation & $\begin{array}{l}\text { Usage of picture, graphs, charts give } \\
\text { clear understanding of the subject }\end{array}$ & 96 & 80.00 \\
\hline 3. & Discussion method & $\begin{array}{l}\text { Facilitates for horizontal flow of } \\
\text { knowledge }\end{array}$ & 114 & 95.00 \\
\hline 4. & Participatory techniques & $\begin{array}{l}\text { Participation make students to } \\
\text { remember subject for long period }\end{array}$ & 68 & 56.67 \\
\hline 5. & Seminars in the class & Gives deep insight about the subject & 76 & 63.33 \\
\hline 6. & Case methods & $\begin{array}{l}\text { Motivates students for initiation of } \\
\text { action and creates interest }\end{array}$ & 70 & 58.33 \\
\hline 7. & Exposure visits & $\begin{array}{l}\text { Gives clear knowledge about real life } \\
\text { situation }\end{array}$ & 108 & 90.00 \\
\hline 8. & $\begin{array}{l}\text { Result and method } \\
\text { demonstrations }\end{array}$ & $\begin{array}{l}\text { Demonstrations improves the students } \\
\text { skills and decision making capacity }\end{array}$ & 67 & 55.83 \\
\hline 9. & Role play & Increases the efficiency of the students & 99 & 82.50 \\
\hline 10. & Video/audio conferencing & $\begin{array}{l}\text { Gives the scope for students to share } \\
\text { knowledge between the institutions and } \\
\text { experts from different places }\end{array}$ & 101 & 84.17 \\
\hline
\end{tabular}

* Multiple responses may occur 